\title{
Physics Learning Device Development Based On Emotional Intelligence
}

\author{
Agustinus Jarak Patandean \\ Faculty of Mathematics and Natural Sciences, Universitas Negeri Makassar, Indonesia
}

\begin{abstract}
This study aims to produce a physics-based tool of emotional intelligence that is valid, practical, and efficient to improve student learning motivation conducted in two trials. The research location is Junior High School Makassar City with Class VIII D sample of 30 students. The research indicators used are 1) ultimate learning tools, 2) practical learning tools, and 3) effective learning tools to improve students' learning motivation. Data were collected through later trials and analyzed descriptively. The result of the research shows that (1) the learning device is valid based on expert validation because all aspects of the invention are considered valid, (2) Learning tool is practical because all facets of the learning device components fully implemented, (3) learning tools are useful because Fulfilled student activity performed entirely, student response to learning device in active category, high student learning motivation.
\end{abstract}

Keywords: Learning Tool, Emotional Intelligence, Learning Motivation

\section{Introduction}

Along with the advancement of science and technology, it is necessary to prepare the next generation capable of utilizing, developing, and mastering science and technology, to adapt to the progress of science and technology and not always depend on developed countries. The original solution for this is to prepare a reliable human resource through education. The above statement is also in harmony with the goals of national education, which listed in the three legal bases of Indonesia, namely the 1945 Constitution, Law no. 20 of 2003 on National Education System, and Government Regulation no. 19 of 2005 on National Education Standards, among which include: 1) Smart, peaceful, independent and fair nation; 2) Have competitiveness in facing global; 3) Qualifications include attitudes, knowledge, and skills; 4) Have a basis of intelligence, knowledge, personality, noble character, as well as skills to live independently, and follow further education; 5) Have life skills including personal skills, social skills, academic skills, and vocational skills [1].

One of the learning tools that will be studied by researchers to teach the concept of the material of physics is the learning device based on emotional intelligence so that student learning motivation becomes more comprehensive than before. The results of research on the application of learning tools obtained the result that the implementation of the learning device model can cultivate the character, positive attitude, and learners attitude [1]. The results of the growth of moral values obtained will be used as a mirror student to act or act, both in the school environment and in the community. The phase/syntax of the emotional intelligence-based learning model aims to cultivate good manners, positive traits, and learners alike.

Education is a broader process in the processes that take place within the school. The Law of the Republic of Indonesia Number 20 the year 2003 explains that education is a conscious and planned effort to create an atmosphere of learning and learning process so that learners actively develop their potential to have spiritual power of religion, self-control, personality, intelligence, noble character, Needed him, society, nation, and state.

Learning is an activity that involves various components, among others: students, teachers, curriculum, educational facilities, and infrastructure. Teachers include a critical element in the learning process, which has responsibility and is crucial to achieving the success of education. Before implementing the lesson, teachers are required to pay attention to the various components of the learning system that include: preparing lesson plans, making the relevant material, designing methods tailored to the situation and conditions of the students, providing educational resources and media [2].

Learning tools that include: syllabus, Learning Plan (RPP), student materials and Student Worksheets (LKS) are significant things that must make and must be considered by the teacher because learning tools play a major role in the success of the learning process. Each teacher in an educational unit is obliged to develop a complete and systematic learning tool for learning to be interactive, inspirational, fun, challenging, motivating students to participate actively, creativity and independence according to students' physical and psychological talents, interests, and development [3].

School physics education at all levels of formal education is still concerned with cognitive aspects. In general, science learning using lecture method, then ended the assignment of home duties, so that students do not discover the laws of physics through experiments performed. One of the problems faced in the study of science is the unfulfilled quality of learning is expected by the demands of the curriculum both process and learning outcomes so that the students' learning motivation in the small category. This is because (1) the knowledge has not been systematically considering the aspects of emotional intelligence that support the achievement of learning objectives, (2) the learning tools used are not yet visible aspects of emotional intelligence, and (3) the results of interviews of physics teachers who Said that teachers' insights 


\section{International Journal of Science and Research (IJSR) \\ ISSN (Online): 2319-7064}

Index Copernicus Value (2015): 78.96 | Impact Factor (2015): 6.391

are still lacking about learning models and learning devices based on emotional intelligence [4].

Achievement of high education performance required learning tools to support the implementation of the learning process. Learning tools developed in this study include Learning Implementation Plan (RPP), student book and Student Worksheet (LKS). The use of media can help teachers in explaining material that is difficult for students to understand. Media as one learning tool that can be used to assist in the learning process Development of learning tools is important to contribute to improving the effectiveness of physics education. Learning tools developed are expected to be models or models for teachers and can provide a stimulus for teaching staff' creativity to develop other learning tools that can be used in the learning process [5].

The success of physics teaching is also inseparable from the role of the teacher. In the education system, teacher factor is one of the most important links. Teachers are one of the most strategic components of the micro-educational system and take many roles in the educational process [6]. Thus, the success of physics teaching in Junior High School is due to factors of laboratory management system and teacher factor.

Intellectual Intelligence (IQ) accounts for only $20 \%$ of success, while $80 \%$ is a contributory factor of other forces, such as emotional intelligence or emotional quotient (EQ), self-motivating ability, overcoming frustration, controlling the urge of the heart, Empathize and capacity to work together [7].

In the process of student learning, both bits of intelligence is indispensable. IQs cannot function well without the participation of heartfelt appreciation of subjects delivered at school. But usually, the two pieces of information are complementary. The balance between IQ and EQ is the key to student learning success in school [7]. Education in schools not only need to develop rational intelligence is a model of understanding that is usually understood only students, but also needs to develop emotional intelligence students.

Learning not only takes into account the cognitive aspect but also pays attention to other issues such as emotional intelligence [8]. In this regard, to attain sufficient emotional intelligence through teaching and learning, the emotional intelligence issues need to be addressed. Particular concern because the sensitive intelligence issue seen as an element that can be used as a basis to follow the learning process based on emotional intelligence well.

\section{Research Methods}

This research is a study of learning device development involving 30 students of class VIII D Junior High School (SMP) 24 City of Makassar academic year 2013/2014. The fundamental consideration in the determination of the location of the study is because the learning tools not based on emotional intelligence that is implemented in schools to improve students' learning motivation. The research method used is the method of developing extensive teaching materials
[9]. The study was conducted in two experimental studies, consisting of four components: (1) syntax components, (2) social system components, (3) reaction principle compounds, and (4) component support systems. Each trial conducted in four lessons and one final test of action.

The teacher presents an overview of the implementation of emotional intelligence-based learning and indicators that will serve as guidance in student learning. The research indicators used are 1) ultimate learning tools;, 2) practical learning tools; , and 3) effective learning tools to improve students' learning motivation.

Emotional intelligence-based learning steps are 1) student apperception, 2) knowledge construction, 3) recitation, 4) guide practice, and 5) evaluation and reward.

The data collected are 1) effective learning device data including syntax, social system, reaction principle, and support system; 2) data on the effectiveness of learning tools include: student activities, student responses to learning tools, and student learning motivation. Student response data is analyzed descriptively with success criterion is student response at least categorized positively, student activity toward learning device with success criteria all activity fulfilled in whole, and data of student motivation is analyzed descriptively, with measures of achievement and happened improvement of student learning motivation from the trial I To test II.

\section{Results}

The study of learning device development was carried out with some students as many as 30 people. Lesson learned subjects packaged in two learning trials, and each trial is broken down into four meetings. Each session is held once a week with time allocation of 3 hours of face-to-face lesson. Beginning of the learning process, teachers who collaborate with the researcher first convey that the learning activities in the classroom implemented by using the tools of learning based on emotional intelligence through a specified learning model. Teachers communicate about learning tools that will apply during the learning process includes three aspects of validity, practicality, and effectiveness to improve student learning motivation.

Based on the results of evaluation and analysis of experts or experts on Test I by the established indicators then obtained the following validity results.

Table 1: Invalid data of Learning Devices

\begin{tabular}{|c|c|c|}
\hline No. & Aspects of Assessed & Results \\
\hline 1 & Lesson Plans (RPP) & Very valid \\
\hline 2 & Student Books & Very valid \\
\hline 3 & Student Activity Sheet (LKS) & Very valid \\
\hline 4 & Student Motivation Questionnaire & Very valid \\
\hline
\end{tabular}

The results of the first trial on the practicality and effectiveness of instructional devices obtained information as follows.

\section{Volume 6 Issue 8, August 2017}




\section{International Journal of Science and Research (IJSR) \\ ISSN (Online): 2319-7064}

Index Copernicus Value (2015): 78.96 | Impact Factor (2015): 6.391

Table 2: Practicality of Learning Devices

\begin{tabular}{|c|c|c|}
\hline No & Aspects of Assessed & Results \\
\hline 1 & Learning Syntax & Fully Implemented \\
\hline 2 & Social System & Fully Implemented \\
\hline 3 & Principle of Reaction & Fully Implemented \\
\hline 4 & Support System & Fully Implemented \\
\hline
\end{tabular}

Table 3: Effectiveness of Learning Devices

\begin{tabular}{|c|c|c|}
\hline No & Aspects of Assessed & Results \\
\hline 1 & Student Activity & $\begin{array}{c}\text { Two aspects have not } \\
\text { implemented }\end{array}$ \\
\hline 2 & $\begin{array}{c}\text { Student Response } \\
\text { Devices }\end{array}$ & Positive \\
\hline 3 & $\begin{array}{c}\text { Motivation of Student } \\
\text { Learning }\end{array}$ & Medium Category (0.52) \\
\hline
\end{tabular}

Similarly, the results of evaluation and analysis on Test II by the established indicators then obtained the following validity results.

Table 4: Practicality of Learning Devices

\begin{tabular}{|c|c|c|}
\hline No & Aspects of Assessed & Results \\
\hline 1 & Learning Syntax & Fully Implemented \\
\hline 2 & Social System & Fully Implemented \\
\hline 3 & Principle of Reaction & Fully Implemented \\
\hline 4 & Support System & Fully Implemented \\
\hline
\end{tabular}

Table 5: Effectiveness of Learning Devices

\begin{tabular}{|c|c|c|}
\hline No & Aspects of Assessed & Results \\
\hline 1 & Student Activity & All aspects accomplished \\
\hline 2 & Student Response Devices & Positive \\
\hline 3 & $\begin{array}{c}\text { Motivation of Student } \\
\text { Learning }\end{array}$ & Medium category $(0.80)$ \\
\hline
\end{tabular}

\section{Discussion}

Analysis of trial result I of the above three indicators are presented in the following manner.

\subsection{Validation}

Based on the expert validation results, it is shown that the learning device plan (RPP, Student Book, and student activity sheet (LKS) is very valid so that the instrument can use in the classroom by displaying elements of emotional intelligence Distinguish the other appliance. It expected that the students 'perspective constructs the concept/principle of physics knowledge based on emotional intelligence to improve students' learning motivation. Thus, the material presented is equipped with images to be viewed, analyzed, and can create a fun attraction to learn.

\subsection{Practicality}

Based on the observation of the implementation of learning tools in Test I, it stated that it met the criteria of the element of practicality and improved in the Trial II. These aspects described as follows.

(A) Syntax components, phases of concern to teachers for improvement in learning: (1) Phase 2 (knowledge construction based on emotional intelligence by showing empathy, seriousness, and praise, and (2) Phase 4 (guiding advanced training Based on emotional intelligence, seriously, understanding and give praise), (b) component of social system, on this element aspect that its implementation not yet maximally to be improved is student activity in doing follow up practice both individual and group, (c) component of Reaction Principle, The part of this aspect that needs to be improved is that the teacher trains students' skills which are an emphasis on Trial II.

\subsection{Effectiveness}

(A) The result of the student's response to the plan of the implementation of the tool (RPP), shows that $83.3 \%$ of students give positive responses, that is, generally students declare that the application of learning tools is easy to understand and the guidance of teachers is very impressive, so they are very interested and very interested in; (B) the result of students' responses to the Student Book indicates that above $87 \%$ of students responded positively;, (c) the result of student response to Student Activity Sheet (LKS) showed that $83.3 \%$ responded positively. According to the students the exciting factors of Bulku Siswa and LKS are the appearance factors (writing, drawing) whereas in terms of the language used simple, easy to understand and do not use the words that are difficult to comprehend, (d) the result of student learning motivation shows That 0.52 is in the medium category.

Discussion and analysis of the results of trials II of the above three indicators presented in the following manner. Before conducting Trial II, it is suggested to the teacher to improve the student activity aspects that have not fulfilled during the first test in case: (1) when the teacher teaches students the explanations are motivation, spirit, and encouragement so that students can change the way Learning to be better. Where the material read will be more easily understood because the material equipped with pictures and aspects of emotional intelligence, and (2) The teacher emphasizes doing follow-up work sincerely and honestly. Students apply the expression to recall learning materials that are read in earnest with the need for greater precision and caution when compared to doing the student activity sheet (LKS) exercise.

Taking into consideration some of the suggestions as described above, the results achieved at the second tryst stage are the three aspects of the effectiveness of the aforementioned devices that meet the established criteria: (1) the student activity point has been achieved overall, (3) the student's response to Lesson plans, student bookings and student activities sheets in positive categories, and (3) Student learning motivation has increased to be high. Thus, the results achieved in the implementation of Test II are the three aspects of effectiveness mentioned above have met the criteria set, so that obtained a useful learning tool. 


\section{Conclusion}

Based on the results of data analysis can be concluded as follows.

- Physical learning devices based on emotional intelligence meet stringent criteria based on aspects of teaching device components that have been validated by experts.

- Psychological intelligence-based learning tools meet the functional criteria as all device components fully implemented.

- Implementations of emotional intelligence-based learning methods fulfill the criteria actually because the student activity is done entirely, student responses to active learning tools, and high student learning motivation.

\section{References}

[1] M. Ibrahim, "Model Pembelajaran IPA Inovatif Melalui Pemaknaan," Jakarta Tim Peneliti Balitbang, 2008.

[2] Z. Aqib, "Profesionalisme guru dalam pembelajaran," Surabaya Insa. Cendekia, 2002.

[3] Depdiknas, "Standar Isi Kurikulum Tingkat Satuan Pendidikan." Departemen Pendidikan Nasional, Jakarta, pp. 1-43, 2006.

[4] A. J. Patandean, "Pengembangan Model Pembelajaran Berbasis Kecerdasan Emosional untuk Meningkatkan Motivasi Belajar Siswa Junior High School," Desertation, Universitas Negeri Makassar, Makassar, Indoensia, 2015.

[5] Sartika, Septi Budi., "Pengembangan Perangkat Pembelajaran Fisika Berorientasi Model Pembelajaran Pemaknaan untuk Meningkatkan Hasil Belajar Siswa," Pedagogia, vol. 1, no. 1, pp. 65-84, 2016.

[6] D. Suyanto \& Hisyam, "Pendidikan di Indonesia Memasuki Milenium III: Refleksi dan Reformasi," Yogyakarta Adic. Karya Nusa, 2000.

[7] D. Goleman, Emotional intelligence. Bantam, 2006.

[8] L. E. Shapiro, Mengajarkan Emotional Intelligence Pada Anak. Jakarta, 1998.

[9] T. Plomp, "Educational and training system design," Enschede Univ. Twente, 1997 